\title{
Inocybe praetervisa group - A clade of four closely related species with partly different geographical distribution ranges in Europe
}

\section{Authors: Ellen Larsson, Jukka Vauras, and Cathy L. Cripps}

NOTICE: this is the author's version of a work that was accepted for publication in Mycoscience. Changes resulting from the publishing process, such as peer review, editing, corrections, structural formatting, and other quality control mechanisms may not be reflected in this document. Changes may have been made to this work since it was submitted for publication. A definitive version was subsequently published in Mycoscience, vol. 59, iss. 4, (July 2018) DOI\# 10.1016/j.myc.2017.11.002

Larsson, Ellen, Jukka Vauras, and Cathy L. Cripps. "Inocybe praetervisa group - A clade of four closely related species with partly different geographical distribution ranges in Europe." Mycoscience 59, no. 4 (July 2018): 277-287. DOI: 10.1016/j.myc.2017.11.002.

Made available through Montana State University's ScholarWorks scholarworks.montana.edu 


\title{
Inocybe praetervisa group - A clade of four closely related species with partly different geographical distribution ranges in Europe
}

\author{
Ellen Larsson ${ }^{\text {a, b, }}$, Jukka Vauras ${ }^{c}$, Cathy L. Cripps ${ }^{\mathrm{d}}$ \\ ${ }^{a}$ University of Gothenburg, Department of Biological and Environmental Sciences, Box 461, SE-40530, Göteborg, Sweden \\ b Gothenburg Global Biodiversity Centre, Box 461, SE-40530, Göteborg, Sweden \\ c Biological Collections of Åbo Akademi University, Herbarium, Biodiversity Unit, FI-20014, University of Turku, Finland \\ d Montana State University, Department of Plant Sciences and Plant Pathology, 119 Plant Biosciences Building, Bozeman, MT, 59717, USA
}

\begin{abstract}
A B S T R A C T
Sequence data from a broad geographical region and different habitats show that the Inocybe praetervisa clade is comprised of four closely related species. These species of section Marginatae are characterized by having nodulose spores and a stipe that is abundantly pruinose only in the upper half. Inocybe praetervisa occurs in Southern Europe in mountainous mixed coniferous forests, and is not confirmed from Northern Europe. Inocybe rivularis occurs in northern boreal forests up to the lower alpine zone, associated with Betula in moist habitats, and is not confirmed from Southern Europe. Inocybe taxocystis is confirmed as a later synonym of $I$. favrei. The species has a wide geographical distribution range in Europe, mainly restricted to the alpine zone and moist soils, associated with Salix herbacea. Inocybe arctica is here described as a new species. It occurs in the arctic and higher alpine zones, associated with Dryas octopetala, Salix polaris, S. reticulata and S. herbacea. All species except I. arctica are shown to have an intercontinental distribution range and are confirmed from North America. Sequence data suggest the occurrence of one additional species in the alpine zone of China. A key to the species in the I. praetervisa group is provided.
\end{abstract}

\section{Introduction}

Inocybe section Marginatae Kühner (1933) is known to be comprised of several species complexes where names have been interpreted differently and often misapplied (Esteve-Raventós, Moreno, Bizio, \& Alvarado, 2015, 2016; Jacobsson \& Larsson, 2012; Vauras \& Larsson, 2015).

The species in Marginatae are usually characterized by the absence of a cortina, having nodulose spores and caulocystidia descending to the base. However species in the I. praetervisa clade, as defined by Esteve-Raventós et al. (2016), have abundant caulocystidia in the upper half that are sparse or absent in lower half of the stipe. In this recent paper dealing with the taxonomy of the Inocybe praetervisa group (Esteve-Raventós et al., 2016) a lectotype for I. praetervisa Quél. was selected. In addition, an epitype was designated, from a representative specimen of the Bresadola herbarium collected from the type locality in Italy in order to fix the name also by sequence data of the internal transcribes spacer (ITS) region (Ariyawansa et al., 2014).

In morphology, I. praetervisa is characterized by having a smooth yellowish-brown pileus that becomes darker brown with age and a margin that is rimose. The lamellae are at first pale white with a greyish tint, and are later more brown. The stipe is pale whitish at first and later yellowish brown, possesses a more or less marginate bulbous stipe base, and is densely pruinose in the upper half. Spores are heterodiametric and distinctly nodulose. Cheilo- and pleurocystidia are utriform to broadly fusiform, and rather thick-walled with crystals at the apex. Specimens become darker brown upon drying but are not blackening. The selected epitype, collected by Bresadola, originates from a coniferous forest. For a more detailed description see Esteve-Raventós et al. (2016).

In the Esteve-Raventós et al. (2016) study, phylogenetic analyses based on ITS sequences were performed to infer phylogenetic relationships among the species. In the phylogeny presented, the sequence of a paratype of I. rivularis Jacobsson \& Vauras fell within the I. praetervisa clade with strong support, suggesting it should be a later synonym of $I$. praetervisa. Accordingly, based on the 
phylogenetic results and the similarity in morphology I. rivularis was regarded as a synonym of I. praetervisa (Esteve-Raventós et al., 2016).

Inocybe rivularis was described by Jacobsson and Vauras (1989) from moist forest habitats in the boreal zones of Fennoscandia, likely associated with Betula spp., Picea abies (L.) H. Karst. and Salix spp. The species is considered to have a rather wide distribution and is common in suitable habitats, usually close to small spring brooks. In morphology it is rather similar to the description of I. praetervisa (Esteve-Raventós et al., 2016) but was characterized as having a cortina in young specimens that soon disappears leaving no remnants on the stipe. The stipe base is clavate to bulbous but not marginately bulbous. As the species was densely pruinose only in the upper part of the stipe it was at first thought to belong in section Cortinatae Kühner.

A species with similar morphology is I. taxocystis (J. Favre) Singer. The species was first described by Favre (1955) as a variety of I. decipientoides Peck (I. decipientoides var. taxocystis Favre), from the Swiss alpine zone associated with Salix herbacea L. and Dryas octopetala L. Favre's variety was characterized by having a stipe that is pruinose at least to half the stipe, glabrous below, with a bulbous but not marginate stipe base. It was first raised to species level by Singer (1986), but without selecting a lectotype. It was also described as the new species Asterosporina taxocystis J. Favre \& E. Horak by Horak (1987), and later moved to Inocybe (Fr.) Fr. by SennIrlet (1992).

Another species with similar morphology and habitat was published as I. favrei Bon (1985). The species was described with a stipe that is more or less pruinose particularly in the upper half and with an obtusely marginate stipe base, and is associated with S. herbacea, S. reticulata L. and Dryas. The species was described by Bon to accommodate the description of the species I. decipiens Bres. sensu Kühner by Favre from the alpine zone (Favre, 1955). Bon designated a holotype (Bon 84095) from the alpine zone in France associated with $S$. herbacea.

Analyses of ITS sequence data have become an important tool for evaluating the morphological characters used to determine and diagnose species. This has been especially valuable for groups with morphologically similar characters and seemingly broad ecology as often encountered within Inocybe (Cripps, Larsson, \& Horak, 2010; Kokkonen \& Vauras, 2012; Larsson, Vauras, \& Cripps, 2014; Vauras \& Larsson, 2015). The ITS region is now agreed upon as the bar code marker for fungi (Schoch et al., 2012) and has been found to be suitable and to work well for delimitation and segregation of species in the majority of the Basidiomycetes (Kõljalg et al., 2013).

In the present study, we compare morphology and sequence data of a broader sampling of specimens determined as I. rivularis, I. taxocystis and I. favrei, to get a better picture of I. praetervisa sensu Esteve-Raventós et al. (2016).

\section{Material and methods}

\subsection{Morphological methods}

The majority of the sequenced specimens were collected by the authors. Additional material received as loans from different herbaria were studied (AH, G, LIP, O, TUR, S, UPS). Abbreviation of herbaria follows Index Herbariorum (http://sweetgum.nybg.org/ science/ih/).

Macro-morphological characters were noted and cross-sections drawn from some fresh basidiomata. The color codes refer to Cailleux (1981). Micro-morphological characters were measured and drawn from dried material mounted in $10 \% \mathrm{NH}_{4} \mathrm{OH}$ solution following the methodology described in Vauras and Kokkonen (2009).
Photos of micro-morphological characters were made using an Axioskop 2 (Zeiss, Oberkochen, Germany) light microscope and the AxioVision software (http://www.zeiss.com/microscopy/int/home. html).

\subsection{Molecular methods}

Sixty-three specimens from Northern Europe, Svalbard, and North America were targeted for sequencing in this study, including the holotype of I. favrei (Bon 84095, LIP!). In addition the ITS sequence of the lectotype of I. taxocystis (JN580884) and paratype of I. rivularis (JN580885) from the study by Kokkonen and Vauras (2012), the epitype of I. praetervisa (KT201675), I. tabacina FurrerZiogas and I. phaeosticta Furrer-Ziogas from the study by EsteveRaventós et al. (2016) were included. Also a few additional ITS and LSU sequences of Inocybe section Marginatae published in Ryberg, Larsson, and Jacobsson (2010) were included. For comparison and rooting of trees the sampling was selected to correspond with Clade B in Esteve-Raventós et al. (2016). Sequence data of the ITS and LSU regions of I. fibrosoides Kühner (EL51-14; Genbank KY033846) and I. decemgibbosa (Kühner) Vauras (JV8115; Genbank KY033847) were generated. Each target ITS sequence type was also blasted in GenBank (Clark, Karsch-Mizrachi, Ostell, \& Sayers, 2016) and the UNITE database (Kõljalg et al., 2013) to search for additional data generated from specimens, environmental samples as soil and ectomycorrhizae. In all 13 sequences were found and added to the data set.

Sequences from the complete internal transcribed spacer (ITS) region and about 1400 or 375 base pairs (bp) of the $5^{\prime}$ end of the large subunit (LSU) of the nuclear ribosomal DNA were generated. DNA extractions were performed using DNeasy Plant Mini kit (Qiagen, Hilden, Germany), PCR reactions using Illustra PuReTaq ${ }^{\mathrm{TM}}$ ReadyToGo PCR beads (GE Healthcare, Buckinghamshire, United Kingdom). For PCR clean up QIAquick PCR purification kit (Qiagen, Hilden, Germany) was used. The DNA from the type specimen was extracted using a CTAB method, and primers for PCR followed protocols described in Larsson and Jacobsson (2004). Primers used to amplify the complete ITS region and the $5^{\prime}$ end of the LSU region were ITS1F (Gardes \& Bruns, 1993) and LR21, LR0R, and LR7 (Hopple \& Vilgalys, 1999). Primers used for sequencing were ITS1, ITS4 (White, Bruns, Lee, \& Taylor, 1990), Ctb6 (https://nature.berkeley. edu/brunslab/), LR3R and Lr5 (Hopple \& Vilgalys, 1999).

Sequences were edited and assembled using Sequencher 5.1 (Gene Codes, Ann Arbor, Michigan). Sequences generated for this study have been deposited in GenBank and accession numbers given (KY033785-KY033847). Specimens sequenced in this study are indicated with an asterix $\left({ }^{*}\right)$ and the GenBank number is noted in the list of specimens examined.

Alignment was performed using the L-INS-i strategy as implemented in MAFFT v. 7.017 (Katoh \& Standley, 2013). The alignment was adjusted using Aliview 1.17.1 (Larsson, 2014). For inferring phylogenetic relationships among species heuristic searches for the most parsimonious trees were performed using PAUP* (Swofford, 2003). All transformations were considered unordered and equally weighted. Variable regions with ambiguous alignment were excluded and gaps were treated as missing data. Heuristic searches with 1000 random-addition sequence replicates and TBR branch swapping were performed, saving at most 25 trees in each replicate. Relative robustness of clades was assessed by the bootstrap method using 1000 heuristic search replicates with 100 random taxon addition sequence replicates and TBR branch swapping, the latter saving at most 100 trees in each replicate. In addition a Bayesian analysis was carried out in MrBayes 3.2.6 (Ronquist \& Heulsenbeck, 2012), with a best-fit model of nucleotide evolution supplied by MrModeltest 2.2 (Nylander, 2004). Eight 
default-setting Metropolis-Coupled Markov Chain Monte Carlo (MCMCMC) chains were run for 10 million generations with trees sampled every 5000 generations and an initial burn-in of 1000 trees. After discarding the trees prior to the burn-in threshold a $50 \%$ majority-rule consensus phylogram was computed from the remaining trees.

\section{Results}

The aligned complete dataset consisted of 95 sequences and 2095 characters. After exclusion of ambiguous regions mainly from the beginning and the end of the data set 1977 characters remained for the analysis. Of these, 1670 were constant, 57 were variable but parsimony uninformative, and 250 (12.6\%) were parsimony informative. The maximum parsimony analysis yielded 18,950 equally most parsimonious trees (length $=460$ steps, $\mathrm{CI}=0.8217$, and $\mathrm{RI}=0.9359$ ). The $50 \%$ majority-rule consensus bootstrap tree is presented in Fig. 1. The bootstrap analysis recovered the I. praetervisa complex with $100 \%$ support. Five supported clades with low to strong bootstrap support were found within the complex corresponding to I. praetervisa (91\%), I. favrei (95\%), I. rivularis (54\%), Inocybe sp. (100\%), I. arctica (see taxonomy section, $83 \%$ ). The four last clades form a subclade within the complex with a support value of $71 \%$.

As suggested by MrModeltest, the nucleotide evolution model $\mathrm{HKY}+\mathrm{G}$ was used for the ITS1 spacer; K80 was used for the $5.8 \mathrm{~S}$ gene; HKY + 1 was used for the ITS2 spacer, and GTR + I was used for the LSU in the Bayesian analysis. The MCMC analysis converged well in advance of the burn-in threshold and chain mixing was found to be satisfactory, as assessed by using Tracer v1.5 (Drummond, Suchard, Xie, \& Rambaut, 2012). Also in the Bayesian analysis, the I. praetervisa complex was recovered as monophyletic with strong support (a Bayesian posterior probability (BPP) of 1.00). The Bayesian tree topology is similar to the MP bootstrap tree. The same major clades supported in the bootstrap analysis were also recovered in the Bayesian analysis, and the I. rivularis clade, with only $54 \%$ bootstrap support, received no support. BPP values are indicated on the corresponding branches in Fig. 1.

\section{Taxonomy}

Inocybe arctica E. Larss., Vauras \& C.L. Cripps, sp. nov. Figs. 2, 3A-F, 4A, B, 5A-C.

MycoBank no.: MB 820654.

Diagnosis: Medium sized to fairly small species with brown to dark brown pileus, often with frosty remnants of velum, stipe abundantly pruinose at apex but caulocystidia less frequent to rare at the base, spores nodulose, $(10.3-) 11.0-13.1(-14.0) \times(6.5-)$ 6.8-8.7(-9.2) $\mu \mathrm{m}$, pleurocystidia $(50-) 56-82(-88) \times(11-)$ $13-22(-28) \mu \mathrm{m}$. Closely related to I. rivularis and I. favrei but differs from these by having on average longer and more narrowly ventricose pleurocystidia and slightly larger spores, a distribution range in the arctic and higher alpine zones and with preferences for more rich and calcareous soils, associated with Dryas octopetala and dwarf Salix spp., and by having a different ITS sequence.

Type: NORWAY, Troms, Parasdalen, fjeld Paras, SW slope, alpine zone, in a snowbed, among Salix polaris Wahlenb. and Bistorta vivipara (L.) Gray, $69^{\circ} 05^{\prime} \mathrm{N}, 20^{\circ} 10^{\prime} \mathrm{E}, 12$. VIII. 1986, Jukka Vauras 2238F, (Holotype TUR-A 147440, Isotypes GB, MONT, WTU, GenBank no. KY033843).

Etymology: Refers to the area of distribution of the species.

Pileus 1-3.5 cm, when young conical to plano-convex, later more applanate, flat to broadly or indistinctly umbonate, margin deflexed, often somewhat undulate; dirty brown with yellowish tinge, or dark brown, fibrils often dark brown, subtomentosesmooth around disc, outwards radially fibrillose-felty, often with frosty or more abundant whitish velipellis, sometimes cracking into squares. Lamellae moderately crowded, up to $6 \mathrm{~mm}$ broad, narrowly adnate to adnexed, initially pale yellowish $(71 \mathrm{~K})$, then pale greyish brown with yellow tinge (70L), later yellowish brown $(69 N)$. Stipe $1-3.5 \times 0.3-0.7 \mathrm{~cm}$, often equal, base bulbous but not marginate, yellowish, apex often with reddish tint, base whitish, distinct pruinose at apex and in the upper half, but few in the lower part, longitudinally striate, silky shiny. Cortina fugacious, scarce, whitish, present in young basidiomata. Flesh whitish to pale brown, in stipe also pale yellowish brown, sometimes with reddish tint at apex, shiny. Smell indistinct to slightly spermatic. Spores nodulose, heterodiametric, fairly dark yellow-brown, (10.3-) 11.0-13.1(-14.0) $\times(6.5-) 6.8-8.7(-9.2) \mu \mathrm{m}$, on average $12.0 \times 7.6 \mu \mathrm{m}$, range of mean values $11.5-12.2 \times 7.2-7.9 \mu \mathrm{m}, \mathrm{Q}=$ (1.35-)1.4-1.8(-1.9), on average 1.57 , range of mean $Q$-values 1.49-1.69 (120 spores from 6 collections). Basidia (29-) $30-43(-44) \times 11-14(-16) \mu \mathrm{m}$, on average $35 \times 13 \mu \mathrm{m}$, generally 4 spored (47 basidia from 6 collections). Pleurocystidia with crystals $(50-) 56-82(-88) \times(11-) 13-22(-28) \mu \mathrm{m}$, on average $70 \times 17 \mu \mathrm{m}$, range of mean values $65-77 \times 14-20 \mu \mathrm{m}$ (100 pleurocystidia from 6 collections), cylindrical to narrowly utriform, with up to $4 \mu \mathrm{m}$ thick, pale yellow wall. Cheilocystidia with crystals 44-72 $\times 13-26 \mu \mathrm{m}$, on average $59 \times 19 \mu \mathrm{m},(\mathrm{n}=26)$, abundant, paracystidia $10-32 \times 9-13 \mu \mathrm{m}(\mathrm{n}=11)$. Caulocystidia at stipe apex thick-walled, abundant, often with crystals (30-) $38-62(-65) \times(12-) 14-21(-22) \mu \mathrm{m}$, on average $49 \times 18 \mu \mathrm{m}$, $(\mathrm{n}=21)$, more rare but present to stipe base. Cauloparacystidia at stipe apex $17-38 \times 11-16 \mu \mathrm{m}(\mathrm{n}=8)$, few of them thick-walled.

Habitat: Growing in small groups but also single, mainly associated with Salix polaris, S. reticulata L., Dryas octopetala but also Bistorta vivipara and S. herbacea. Usually found on somewhat more rich and calcareous soils. Once found in a mountain birch forest close to the treeline.

Distribution: So far known from the arctic and higher alpine regions on Svalbard and Fennoscandia.

Specimens examined: FINLAND, Enontekiön Lappi, Enontekiö, Kilpisjärvi, Pikku-Malla, forest with Betula pubescens Ehrh. subsp. czerepanovii (N.I. Orlova) Hämet-Ahti, Betula nana L., and Salix spp. near timberline, herb-rich site, by path, 19 Aug 2004, J. Vauras 21746* (TUR-A; GenBank KY033844). NORWAY, Svalbard and Jan Mayen, Svalbard, Nordenskiöld Land, Adventsdalen, Endalen, moist with Salix herbacea and Bistorta vivipara, 10 Aug 2015, E. Larsson 5615* (GB; GenBank KY033827); 14 Aug 2009, with Salix polaris, E. Larsson 77-09* (GB; TUR-A; GenBank KY033828); 14 Aug 2009, in matt of Dryas octopetala, E. Larsson 80-09* (GB; GenBank KY033832); 14 Aug 2009, G. Gulden 181/09* (O; GenBank KY033833); Svalbard, Nordenskiöld Land, Adventsdalen, Todalen, with S. polaris and Dryas octopetala, 21 Aug 2002, leg. C. Cripps, CLC1923* (MONT; GenBank KY033826); 21 Aug 2002, leg. C. Cripps, CLC1925 (MONT); Svalbard, Nordenskiöld Land, Kapp Linné, 8 Sep 2009, G. Gulden 128/09* (GB; GenBank KY033833); Svalbard, Nordenskiöld Land, Longyearbyen, close to the old churchyard, with Dryas octopetala and Salix polaris, 7 Aug 2015, E. Larsson 1815* (GB; TUR-A; GenBank KY033830); 7 Aug 2015, with Dryas octopetala and Salix polaris, E. Larsson 16-15* (GB; GenBank KY033836); Svalbard, Nordenskiöld Land, Longyearbyen, with Dryas octopetala and Salix polaris, 8 Aug 2009, E. Larsson 34-09* (GB; TUR-A; GenBank KY033837); 12 Aug 2009, with Dryas octopetala, Salix polaris and Bistorta vivipara, E. Larsson 50-09* (GB; GenBank KY033838); 8 Aug 2015, moist area with Dryas octopetala and Salix polaris, E. Larsson 30-15 (O; NOBAS2288, KY033834); Svalbard, Nordenskiöld Land, Longyearbyen, Nybyen, with Dryas octopetala and Salix polaris, 17 Aug 2009, E. Larsson 123-09* (GB; 


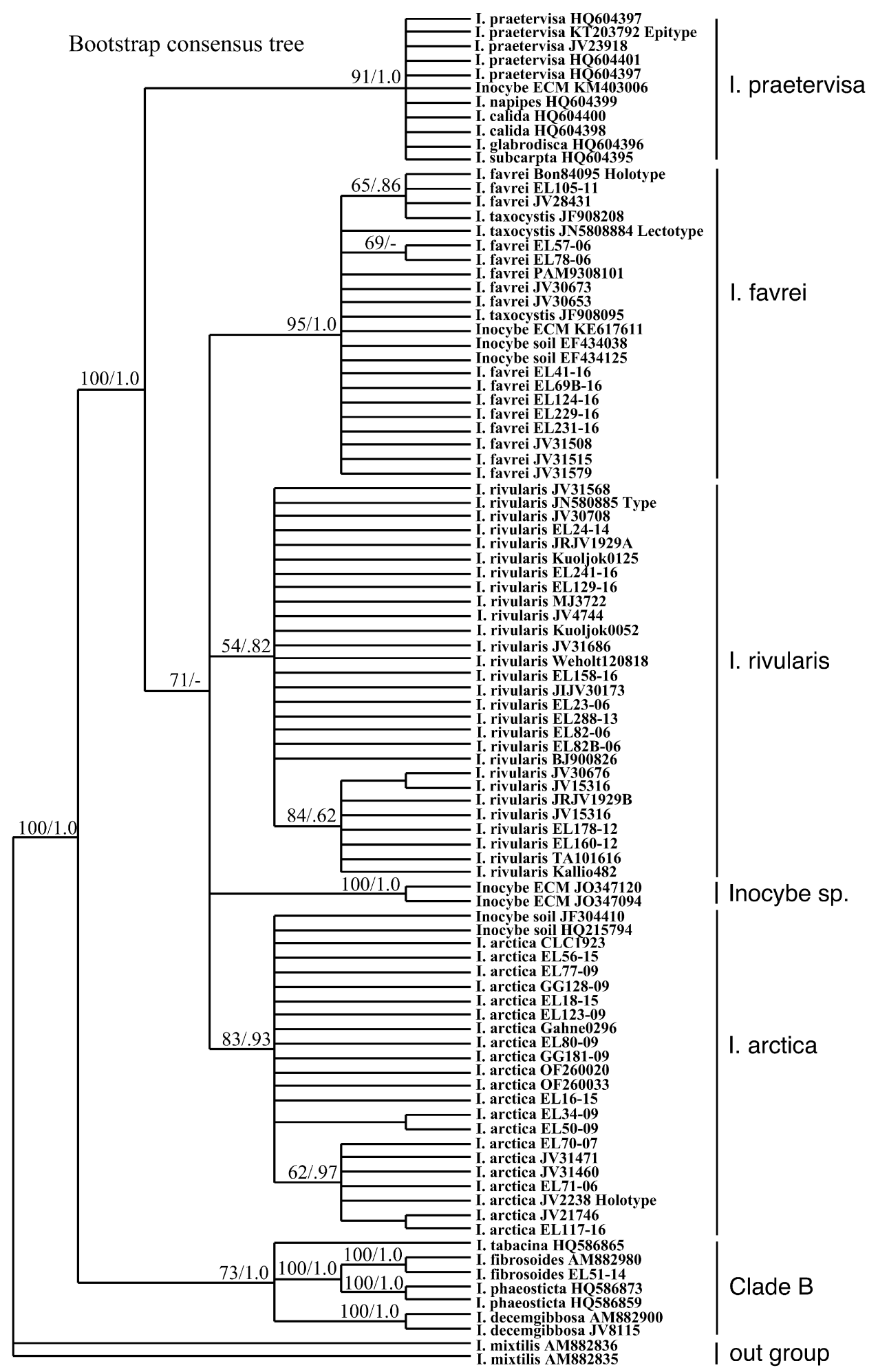

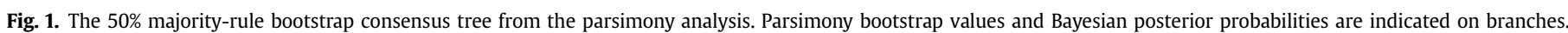

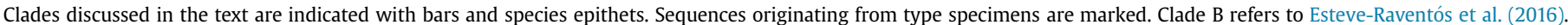

GenBank KY033831); Svalbard, Nordenskiöld Land, Longyearbyen. 2002, B. Gahne 02-96 (GB; GenBank AM882980); Svalbard, Nordenskiöld Land, Bolterdalen, moist with Salix polaris, 13 Aug 2015, A. Molia 25-2015 (O; NOBAS2299, KY033835). SWEDEN, Torne Lappmark, Jukkasjärvi, Latnajaure, moist with Salix reticulata, 10 Aug 2007, E. Larsson 72-07* (GB; TUR-A; GenBank KY033839); 7
Aug 2006, with Salix polaris, E. Larsson 71-06* (GB; TUR-A; GenBank KY033842); Lule lappmark, Jokkmokk, Padjelanta NP, Vielgggisbakte on NW side of Vastenjaure Lake, near Salix herbacea and S. reticulata, 12 Aug 2016, J. Vauras 31471* (TUR-A; GB; GenBank KY033840); Lule lappmark, Jokkmokk, Padjelanta NP, Arranoaijvve on $\mathrm{N}$ side of the Vastenjaure Lake, near Salix herbacea, 11 


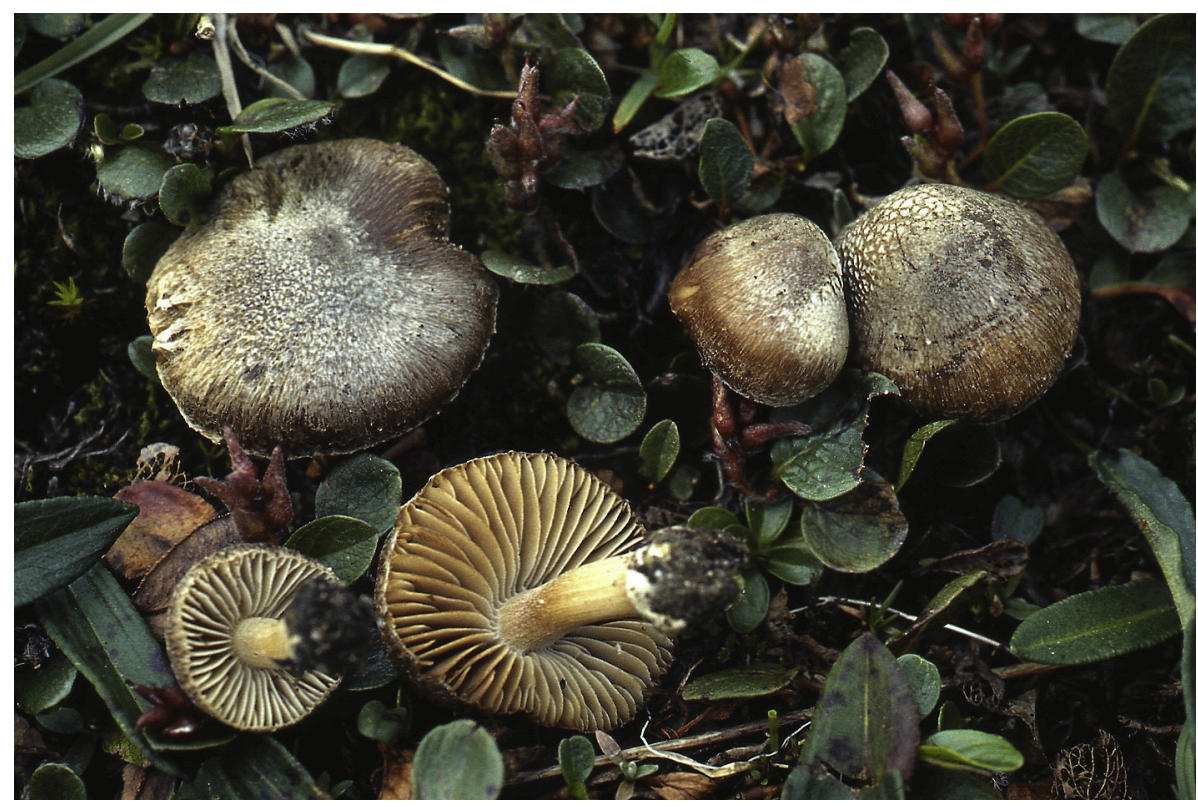

Fig. 2. Inocybe arctica. Basidiomata of the holotype growing with Salix polaris and Bistorta vivipara (J. Vauras 2238F).

Aug 2016, J. Vauras 31460* (TUR-A, GB; GenBank KY033841); Lule lappmark, Jukkasjärvi, Padjelanta NP, Slahpejaure NO, with Salix herbacea, 14 Aug 2016, E. Larsson 117-16* (GB; GenBank KY033845).

Inocybe praetervisa Quél., in Bresadola, Fung. Trident. 1:35, 1881. Fig. 4E, F.

For the description of I. praetervisa, we refer to Esteve-Raventós et al. (2016). The species resembles I. rivularis, but differs somewhat by having smaller spores often with a long apical nodule, on average smaller nodules, and in the form of the pleurocystidia, which tend to attenuate at the apex on average more than in I. rivularis.

Micro-morphological measurements: Spores yellow-brown, $(8.8-) 9.1-11.4(-12.7) \times(6.0-) 6.2-7.4(-8.1) \mu \mathrm{m}$, on average $10.2 \times 6.8 \mu \mathrm{m}$, range of mean values $9.8-10.4 \times 6.5-6.9 \mu \mathrm{m}, \mathrm{Q}=$ $(1.2-) 1.3-1.7(-2.0)$, on average 1.50 , range of mean $\mathrm{Q}$-values 1.49-1.52 (80 spores from 3 collections). Basidia 31-38 × 10-12 $\mu \mathrm{m}$, on average $34 \times 11 \mu \mathrm{m}$, generally 4-spored, clavate ( 8 basidia from 1 collection). Pleurocystidia (55-) $59-83(-92) \times(15-) 18-28(-29) \mu \mathrm{m}$, on average $69 \times 22 \mu \mathrm{m}$, range of mean values $67-71 \times 21-24 \mu \mathrm{m}$ (54 pleurocystidia from 3 collections), mainly fusiform, thick-walled, with up to $4 \mu \mathrm{m}$ pale yellow to yellow wall. Caulocystidia abundant at upper part of stipe, very few or not in the lower half, variable, thick-walled, some cauloparacystidia thick-walled.

Specimens examined: ITALY, Bolzano, NE of Campo Túres, Riva di Túres, coniferous forest, ca. 1600 m, 23 Jul 2006, G. Veroi (J. Vauras 23918*; TUR-A; GB; GenBank KY033785); Trentino, Rabbi, Jul 1909, in coniferous forest, G. Bresadola (S-F229598, epitype); SPAIN, Madrid, Rascafria, Pinus sylvestris and Salix sp., 8 Jul 2013, leg. F. Pancorbo, det. F. Esteve-Raventós AH44415 (AH, GB).

Inocybe rivularis Jacobsson \& J. Vauras, Windahlia18:18, 1990 [1989]. Figs. 4G, H, 5G-I.

For the description of I. rivularis we refer to Jacobsson and Vauras (1989), repeating here only the sizes of spores and pleurocystidia, and the distribution of caulocystidia. Spores (9-) $10-12.5(-13.5) \times 6.5-8.5(-9) \mu \mathrm{m}$, on average $11.1 \times 7.8 \mu \mathrm{m}$, range of mean values $10.5-12.3 \times 7.1-8.1 \mu \mathrm{m}, \mathrm{Q}=1.2-1.6(-1.8)$, average 1.43 , range of mean Q-values 1.35-1.6 (300 spores from 15 collections). Pleurocystidia 50-76(-90) × 14-28(-33) $\mu \mathrm{m}$. With further experience we complement the description and add that sometimes the species can have fairly abundant velipellis on the pileus (Fig. 5C), and with few thick-walled caulocystidia down to base of stipe. Further, it can be found even in the low-alpine zone with Betula nana. Even though this quite large species is fairly common in suitable habitats in northern part of Fennoscandia, there are rather few reports of it (Alpago Novello, 2002). It has been selected as one of the indicator fungi for forests of Finland, associated with spruce mires, brook-side forests and spring habitats (Bonsdorff et al., 2014).

Specimens examined: CANADA, Quebec, Schefferville area, Snowy Channel, alpine region, moist depression, growing by water, 14 Aug 1963, leg. P. Kallio 482*, det. J. Vauras (TUR; GenBank KY033825); 14 Aug 1963, leg. P. Kallio 489b (TUR); ESTONIA, Hiiu, Käina, moist forest with Picea abies, Betula sp., Alnus glutinosa (L.) Gaertn., Populus tremula L., Pinus sylvestris L. and Fraxinus excelsior L., 14 Sep 2010, J. Vauras 27165 (TUR-A; TU; TAA101616, UNITE UDB011734); FINLAND, Oulun Pohjanmaa, Oulu, Sanginsuu, Hakala, 4 Aug 1986, J. Ruotsalainen and J. Vauras 2152F (TUR! Holotype; GenBank JN580885); Inarin Lappi, Utsjoki, Kevo, around Kevojärvi, subarctic birch forest with Salix spp., close to the lake. 30 Aug 2012, E. Larsson 178-12*(GB; GenBank KY033823); 27 Aug 2012, subarctic birch forest with Salix spp., E. Larsson 160-12* (GB; GenBank KY033824); Inarin Lappi, Utsjoki, Kevo, Kevojärvi, W. slope of Korkea-Jehkas, SE of Jehkasjärvi, low alpine slope with small brooks, near Betula nana and Salix spp., amongst moist mosses, 24 Aug 2014, J. Vauras 30708* (TUR-A; GenBank KY033802); Enontekiön Lappi, Enontekiö, Kilpisjärvi, Malla Strict Reserve, Mountain Pikku-Malla, alpine site with Salix spp. and Betula nana, close to snow bed, moist, gently sloping site with mosses and stones, 7 Aug 1985, J. Ruotsalainen and J. Vauras 1929* (TUR-A; GenBank KY033804); Enontekiön Lappi, Enontekiö, Kilpisjärvi, mountain birch forest near small river Tsahkaljohka, rather moist site by path, 13 Aug 1990, J. Vauras 4744* (TUR-A; GenBank KY033808); Enontekiön Lappi, Enontekiö, Kilpisjärvi, E side slope of Jehkas, snow bed area, moist with Salix herbacea, 29 Aug 2013, E. Larsson 288-13* (GB; GenBank KY033815); Kainuu, Ristijärvi, church village, Lukkarila, camping place Ristijärven Pirtti, open 

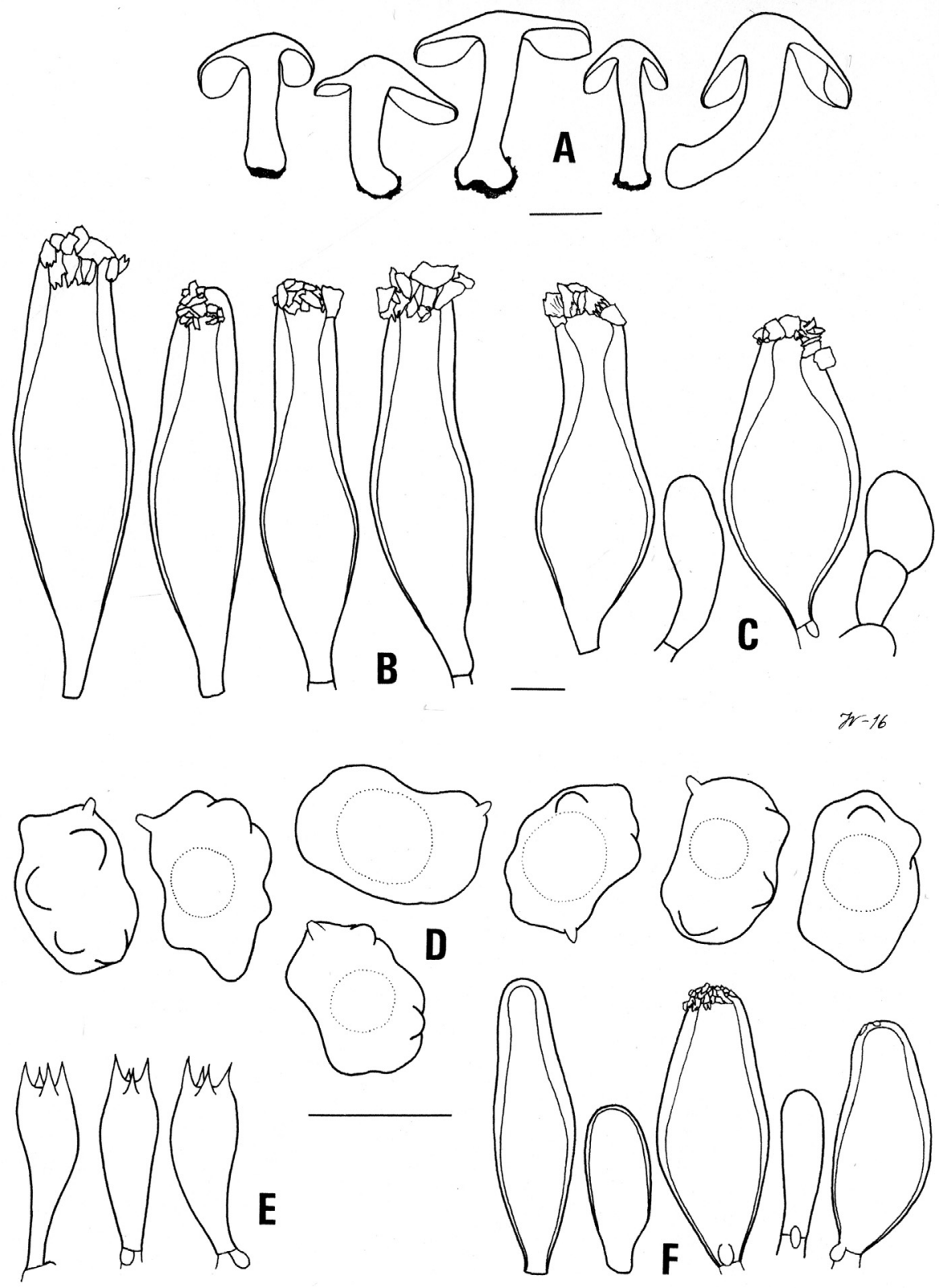

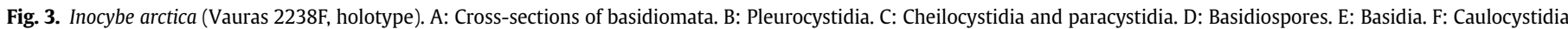
and cauloparacystidia at stipe apex. Bars: A $1 \mathrm{~cm}$; B-F $10 \mu \mathrm{m}$.

park lawn with Betula sp., 27 Aug 2016, J. Vauras 31686* (TUR-A; GB, GenBank KY033810); Pohjois-Häme, Multia, Lehtomäki, E of the farm house, pastured forest on E slope with Picea abies and Betula sp., on mull soil, 8 Sep 2013, J. Issakainen and J. Vauras 30173* (TURA; GenBank KY033813); 8 Sep 2013, E of the farm house, pastured forest on E slope with Picea abies and Betula sp., Pinus sylvestris, Alnus incana (L.) Moench., Populus tremula and Salix caprea L., near brook, J. Issakainen and J. Vauras 30172* (TUR-A; GenBank KY033820); Perä-Pohjanmaa, Rovaniemi, Meltaus, $N$ of the Meltaus - Marrasjärvi, SE of Sortovaara, Kenkäkorpi, herb-rich forest with Picea abies, Populus tremula, Betula sp., Alnus incana, Salix caprea and Pinus sylvestris, with moist depressions, 23 Aug 1999, J. Vauras 15316*(TUR-A; GenBank KY033822); SWEDEN, Lycksele lappmark, Tärna, Hemavan, Portbron, Jobäcken, subalpine Betula pubescens forest with Salix spp., 27 Jul 2014, E. Larsson 24-14* (GB; GenBank KY033803); Lule lappmark, Jukkasjärvi, Padjelanta NP, Huorso,
Vastejaure, among Salix spp., 1 Aug 2001, S. Kuoljok 0125* (GB; GenBank KY033805); 5 Aug 2000, torvkulle med Betula nana, S. Kuoljok 0052* (GB; GenBank KY033809); Lule lappmark, Jukkasjärvi, Padjelanta NP, Njoammeljaure NO, moist with Betula nana and Salix spp., 18 Aug 2016, E. Larsson 241-16* (GB; GenBank KY033806); Lule lappmark. Jukkasjärvi, Padjelanta NP, Njoammeljaure, moist depression on S slope, near Salix spp. and Betula nana, 18 Aug 2016, J. Vauras 31568* (TUR-A; GenBank KY033801); Lule lappmark, Jukkasjärvi, Padjelanta NP, Slahpejaure NO, moist area with small brook, with Betula nana and Salix spp., 14 Aug 2016, E. Larsson 129-16* (GB; GenBank KY033807); Lule lappmark, Jukkasjärvi, Padjelanta NP, Unna Duvgge, moist area with Betula nana and Salix spp., 15 Aug 2016, E. Larsson 158-16* (GB; GenBank KY033812); Torne Lappmark, Jukkasjärvi, Latnajaure, moist with Salix herbacea and Betula nana, 2 Aug 2006, E. Larsson 23-06* (GB; GenBank KY033814); Härjedalen, Tännäs, Andersborgsvägen, moist 


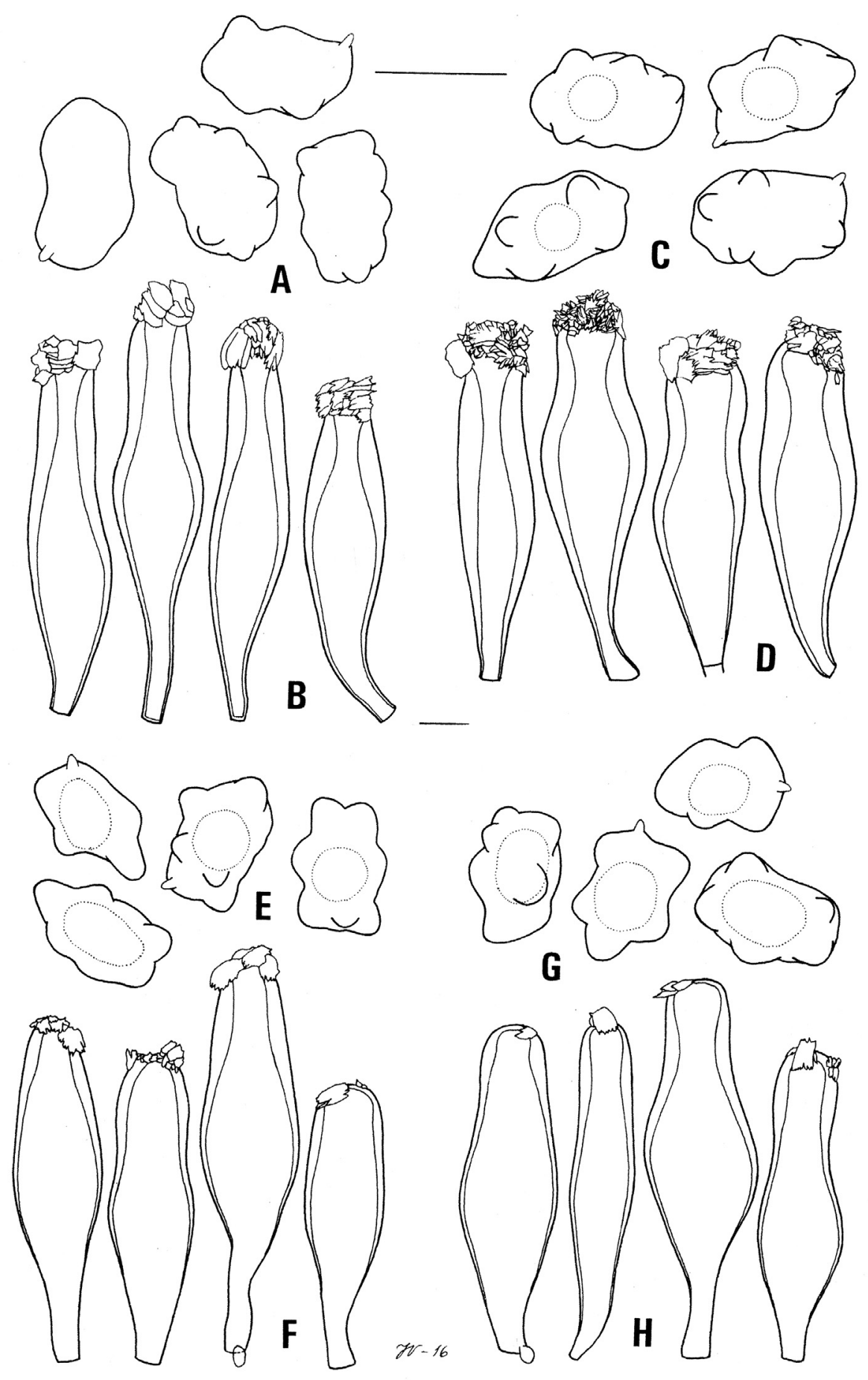

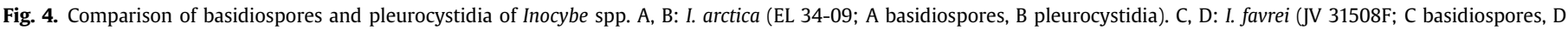
pleurocystidia). E, F: I. praetervisa (JV 23918; E basidiospores, F pleurocystidia). G, H: I. rivularis (EL \& JV $30072 F ;$ G basidiospores, H pleurocystidia). Bars: 10 mm.

area with brooks, Betula pubescens, B. nana and Salix spp., 15 Aug 2006, E. Larsson 82-06* (GB; GenBank KY033817); 15 Aug 2006, E. Larsson 82B-16* (GB; GenBank KY033816); Värmland, Sunne, Gärdesrud, 26 Aug 1990, B. Jansson* (GB; GenBank KY033818); NORWAY, Troms, Storfjord, Lulleslättan, mossy forest with Pinus sylvestris, Betula sp. and scattered Picea abies, on tractor track, 22 Aug 2014, J. Vauras 30676* (TUR-A; GenBank KY033819); Oppland, Valdres, W of Fisketjernsknausen, fjällhed, 7 Jul 1995, M. Jeppson 3722* (GB; GenBank FN550887).
Inocybe favrei Bon, Bull. trimest. Féd. Mycol. Dauphiné-Savoie 25 (no. 97): 28, 1985. Figs. 4C, D, 5D-F, 6A-F.

= Inocybe decipientoides var. taxocystis J. Favre, Ergebnisse der Wissenschaftlichen Untersuchungen des Schweizerischen Nationalparks 5(33): 202, 1955.

$=$ Astrosporina taxocystis J. Favre \& E. Horak, Arctic and Alpine Mycology 2: 230, 1987.

= Inocybe taxocystis (J. Favre \& E. Horak) Senn-Irlet, Bot. Helv. 102(1): 55, 1992. 

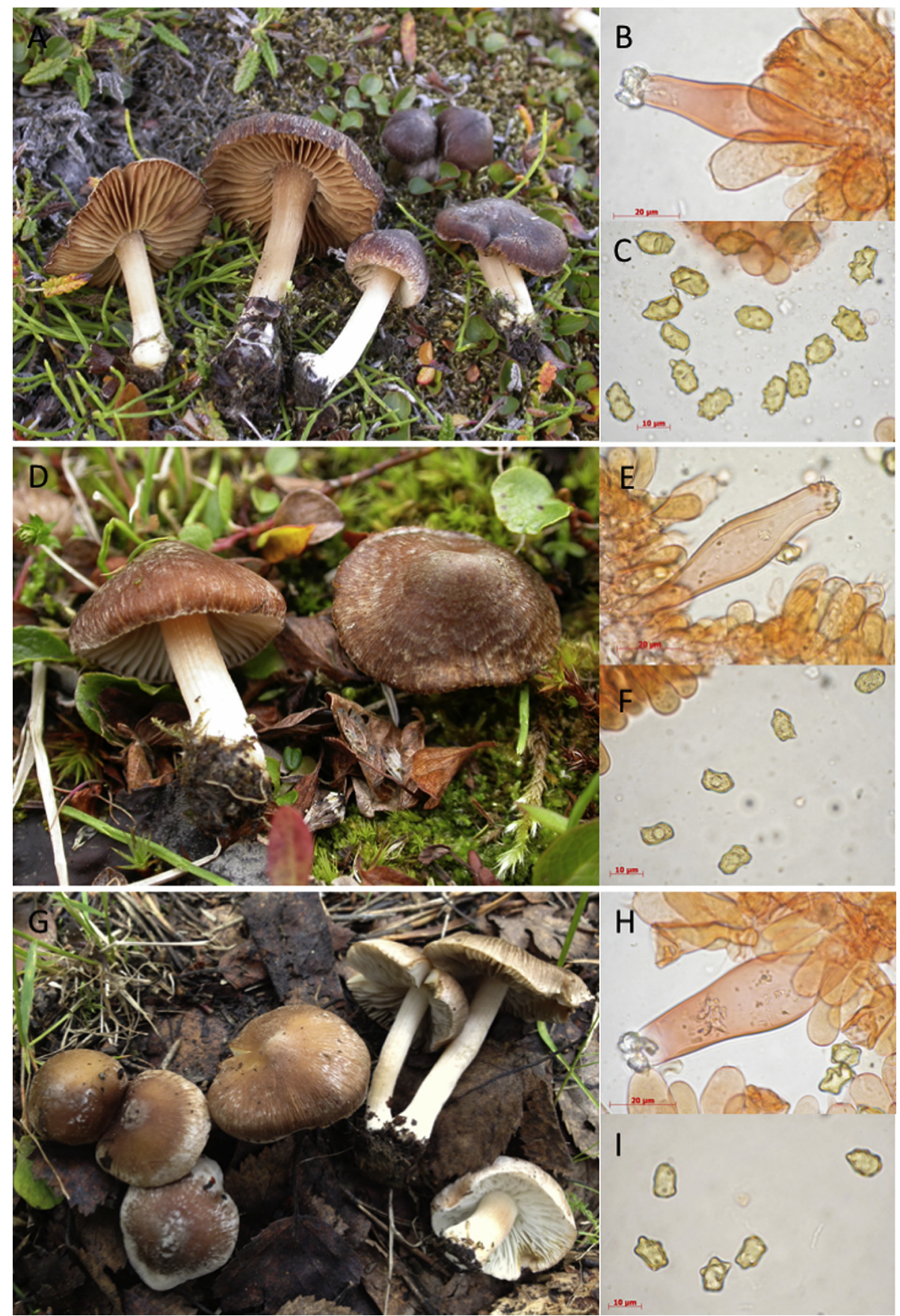

Fig. 5. Photos of Inocybe spp. A-C: I. arctica (EL123-09); A basidiomata, B pleurocystidia, C basidiospores. D-F: I. favrei (EL78-06; D basidiomata, E pleurocystidia, F basidiospores) G-I: I. rivularis (JV30676; G basidiomata, H pleurocystidia, I basidiospores). Bars: B, E, H $20 \mu \mathrm{m}$; C, F, I $10 \mu \mathrm{m}$.

$=$ Inocybe taxocystis (J. Favre) Singer, The Agaricales in modern taxonomy: 604, 1986 (nom. inval., lectotype not selected).

For the description of I. favrei we refer to Bon (1985) and Favre (1955). In macro-morphology, I. favrei resembles I. rivularis and I. arctica. In micro-morphology, it is characterized by having cystidia (both pleurocystidia, cheilocystidia and caulocystidia) that are ventricose and are fairly broad at the apex (see Figs. 4-6). Further, the spores of I. favrei are on average smaller and pleurocystidia shorter and wider compared with I. arctica. The species is most common in the low alpine zone, but has been found on few occasions in forests of the northern boreal zone on calcareous soil.
Micro-morphological measurements: Spores nodulose, but variable in form and size, fairly dark yellow-brown, thick-walled, $(9.7-) 10.3-12.2(-13.5) \times(6.4-) 6.6-8.4(-8.7) \mu \mathrm{m}$, on average $11.2 \times 7.3 \mu \mathrm{m}$, range of mean values $10.9-11.4 \times 7.1-7.5 \mu \mathrm{m}, \mathrm{Q}=$ (1.25-)1.4-1.7(-1.75), on average 1.52, range of mean Q-values 1.50-1.59 (100 spores from 5 collections). Basidia $(28-)$ $29-40 \times(10-) 11-14 \mu \mathrm{m}$, on average $33 \times 13 \mu \mathrm{m}$, generally 4spored, clavate (17 basidia from 4 collections). Pleurocystidia $(54-) 58-74(-80) \times(11-) 14-26(-30) \mu \mathrm{m}$, on average $66 \times 20 \mu \mathrm{m}$, range of mean values $63-70 \times 16-25 \mu \mathrm{m}$ (83 pleurocystidia from 5 collections), mainly ventricose, thick-walled, with up to $4 \mu \mathrm{m}$ pale 


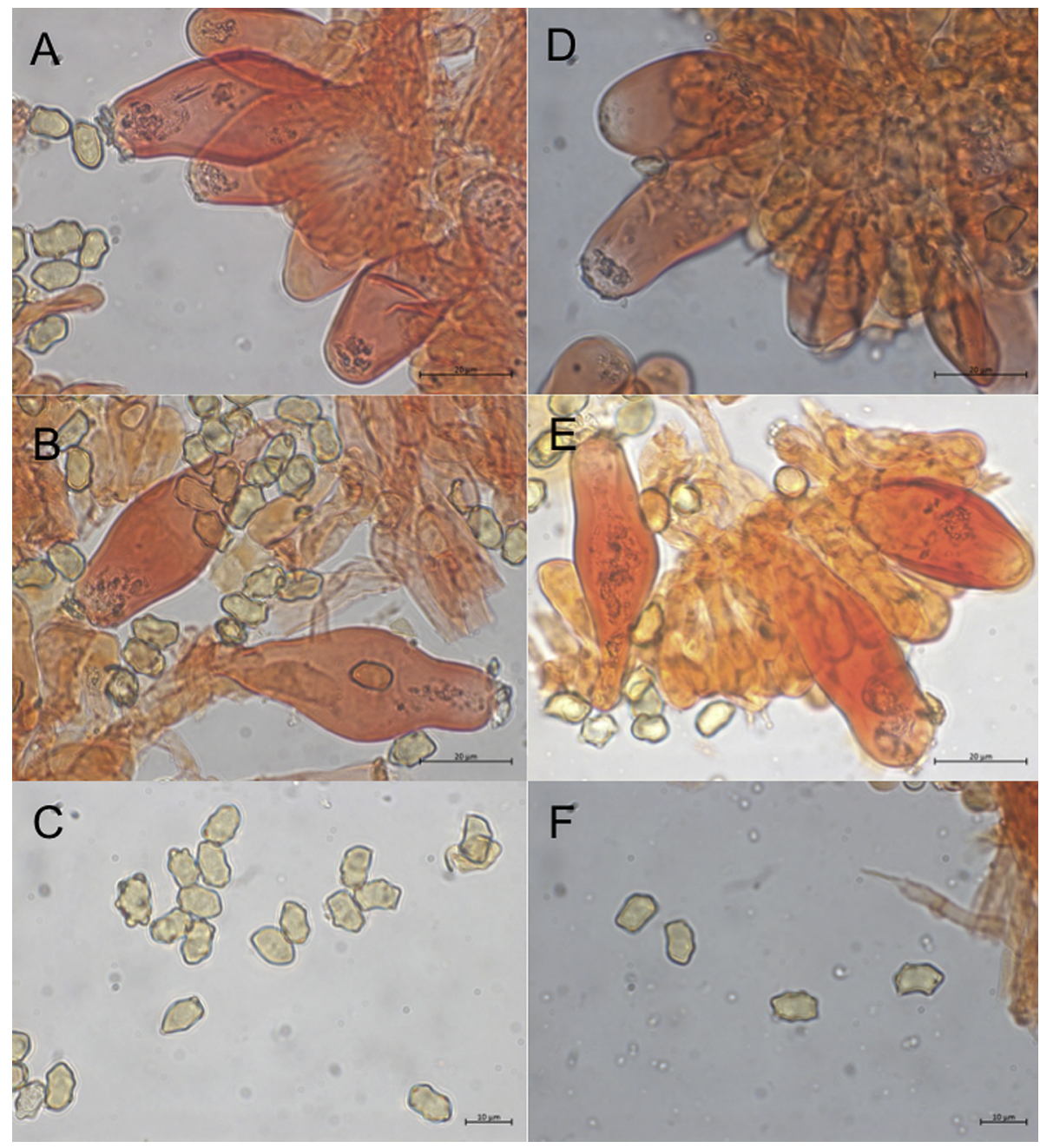

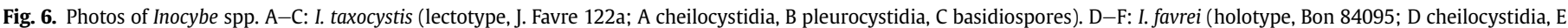
pleurocystidia, F basidiospores). Bars: A, D $20 \mu \mathrm{m}$; C, F $10 \mu \mathrm{m}$.

yellow to yellow wall. Cheilocystidia 44-65 $\times 14-25 \mu \mathrm{m}$, on average $56 \times 19 \mu \mathrm{m}(\mathrm{n}=15)$, mainly ventricose, abundant, paracystidia pyriform, some thick-walled. Caulocystidia abundant at stipe apex, (40-)45-66(-68) × (13-)16-24(-27) $\mu \mathrm{m}$, on average $54 \times 20 \mu \mathrm{m}(\mathrm{n}=20)$, more rare but present to stipe base, variable, thick-walled, some of the cauloparacystidia thick-walled.

Specimens examined: FINLAND, Enontekiön Lappi, Enontekiö, Kilpisjärvi, at border of Finland and Norway, W of the main road, low alpine site at small brook, near Betula nana and Salix spp., 20 Aug 2014, J. Vauras 30653F* (TUR-A; GB; GenBank KY033797); Koillismaa, Kuusamo, Jäkäläniemi, fairly moist forest with Picea abies, Pinus sylvestris and Betula sp., 28 Aug 2011, J. Vauras 28431* (TUR-A; GenBank KY033795); FRANCE, Savoie, Haute-Maurienne, Termignon, Bellecombe, parc national de la Vanoise, 30 Aug 1984, Bon 84095* (LIP, Holotype; GenBank KY033786); Savoie, BourgSaint-Maurice, Arc 2000, lac Marloup, 21 Aug 1993, with Salix herbacea on wet soil along a small lake, higher alpine zone, $2500 \mathrm{~m}$, leg. P.-A. Moreau, PAM93082101* (LIP; GenBank KY033799); NORWAY, Troms, Storfjord, near the border of Finland, Bossovarri, low alpine heath, margin of dried pond, near Salix spp. and Betula nana, 21 Aug 2014, J. Vauras 30673F* (TUR-A; GenBank KY033798); SWEDEN, Torne lappmark, Jukkasjärvi, Latnajaure, with Salix herbacea, 6 Aug 2006, E. Larsson 57-06 (GB; TUR-A; GenBank FN550886); 7 Aug 2006, moist place with Salix herbacea and Bistorta vivipara, E. Larsson 78-06* (GB; GenBank KY033800), 5 Aug
2011, with Salix herbacea, E. Larsson 105-11* (GB; GenBank KY033796); Lule lappmark, Jokkmokk, Padjelanta NP, Arralåbbdå, fjällhed med Salix herbacea, 11 Aug 2016, E. Larsson 41-16* (GB; GenBank KY033794); Lule lappmark, Jokkmokk, Padjelanta NP, Vielgggisbakte, in snow bed area with Salix herbacea, 12 Aug 2016, E. Larsson 69B-16* (GB; GenBank KY033793); Lule lappmark, Jukkasjärvi, Padjelanta NP, Slahpejaure NO, in snow bed area with Salix herbacea, 14 Aug 2016, E. Larsson 124-16* (GB; GenBank KY033792), 14 Aug 2016, on S slope, moist boggy meadow near Salix polaris, S. reticulata, J. Vauras 31508* (TUR-A; GB; GenBank KY033789); 14 Aug 2016, on S slope near Salix herbacea, J. Vauras 31515* (TUR-A; GB; GenBank KY033788); Lule lappmark, Jukkasjärvi, Padjelanta NP, Njoammeljaure NO, with Salix herbacea and Bistorta vivipara, 18 Aug 2016, E. Larsson 229-16* (GB; GenBank KY033791); 16 Aug 2016, snow bed area with Salix herbacea, E. Larsson 231-16* (GB; GenBank KY033790); 16 Aug 2016, at dried pond near Salix and Betula nana, J. Vauras 31579 (TUR-A; GB; GenBank KY033787); SWITZERLAND, Kt. Graubünden, Tarasp, Munt de la Bescha, Salix herbacea, 8 Sep 1945, J. Favre 122a* (G; Lectotype; GenBank JN580884); Val S-charl, Mount Plazer, sur tapis de Salix herbacea, sol gneissique, 20 Aug 1952, J. Favre 122c (G); 26 Aug 1952, J. Favre 122-1 (G). 


\section{Key to the species in the I. praetervisa clade}

1a. Alpine/arctic ecosystems

2.

1b. Forest ecosystems

2a. High alpine to arctic, spores on average 11.5-12.2 $\times$ 7.2-7.9 $\mu \mathrm{m}$, pleurocystidia on average $65-77 \times 14-20 \mu \mathrm{m}$

2b. Sub- to low alpine, spores on average 10.9-11.4 $\times$ 7.1-7.5 $\mu \mathrm{m}$, pleurocystidia on average $63-70 \times 16-25 \mu \mathrm{m}$

I. favrei.

3a. N. Europe and Canada, with Betula, spores on average $10.5-12.3 \times 7.1-8.1 \mu \mathrm{m}$

I. rivularis.

3b. S. Europe and N. America, in coniferous forests, spores on average $9.8-10.4 \times 6.5-6.9 \mu \mathrm{m}$

I. praetervisa.

\section{Discussion}

With the support from phylogenetic analyses of sequence data we show that the I. praetervisa clade is comprised of at least four morphologically and genetically similar but separate species. In addition, two sequences from ectomycorrhizal (ECM) root tips isolated from Kobresia Willd. in the alpine zone of China form a subclade within this grouping, indicating the occurrence of one additional species in Asia. The species show overlapping but partly different geographical distribution patterns in Europe.

Inocybe praetervisa is confirmed to have an intercontinental distribution range. According to our data it occurs in the mountains of Southern Europe then associated with coniferous mixed forests and in Canada associated with Pseudotsuga Carriére. Also, seven sequences deposited in GenBank under various names for collections from British Columbia, lacking information on host or forest type, are $100 \%$ identical with the epitype ITS sequence. So far, we have no specimens or evidence from sequence data of environmental samples that confirm the occurrence of the species in Northern Europe, although it has frequently been reported. However, these reports are based on misinterpretations of the species concept (Esteve-Raventós et al. (2016)). It likely reflects the fact that there are rather many species with similar morphology and traditionally $I$. praetervisa has been treated as a species with a broad species concept in the Nordic countries (Jacobsson \& Larsson, 2012). It was thought to be a species with a more or less completely pruinose stipe, a marginate bulbous stipe base and a pileus and stipe which darken upon drying. All four species treated in this article have abundant caulocystidia at the apex of the stipe, which are more rare but present to the stipe base. In addition, at least $I$. arctica, I. favrei and I. rivularis have a more or less bulbous, not marginate stipe base. This set of morphological characteristics was observed by Kobayashi (1995) when he described the new species I. fastuosa Tak. Kobay., from Tokyo, associated with Pasania Oerst. and Cedrus Duhamel. The species is likely to belong to the same group and fall within the same clade as the species treated here but no sequence data is yet available.

Kokkonen and Vauras (2012) compared sequence data and morphology of the lectotype of I. taxocystis (G13208, J. Favre 122a) with I. rivularis (JV3610, paratype). They found that the two differ in the ITS sequence data by 8 base pairs and 5 insertion deletion events (1-4 bp in length) and somewhat in spore morphology, color of pileus and habitat preferences. They concluded that they should be regarded as separate species: a result that is confirmed by this study.

In our analyses of ITS sequence data from the type specimens of both I. taxocystis and I. favrei fall within the same clade and have identical ITS sequence data (Fig. 1), and according to the rules of nomenclature, the oldest name, I. favrei should be used. This result is also in agreement with the morphology which is very similar (Fig. 6).

Horak (1987) described Astrosporina taxocystis as having a brown to dark brown pileus, occasionally with a reddish tint, an absence of veil, and a pruinose stipe with a marginate bulb at the base. Based on the material he had at hand it should be restricted to acid soils in association with $S$. herbacea, rarely S. retusa L. Bon (1985) described I. favrei to have a pale yellowish brown pileus with cortina (araneoso-velatus), a stipe that is pruinose in the upper part and a bulbous base that is obtusely marginate. This contradiction suggests that determining the presence or absence of a cortina in this group of species can be problematic, or that it is variable. Bon found the species to be indifferent to $\mathrm{pH}$ and occurring in association with S. herbacea, S. reticulata and Dryas octopetala. In our experience I. favrei has a brown color of the pileus, often with a reddish tint, and often also with remnants of velum that form patches (Fig. 5B). Because of the uneven distribution of the caulocystidia on the stipe there has been confusion with these two names. Inocybe favrei has been keyed out to the section Marginatae (Bon, 1997, 1998), and I. taxocystis to the section Cortinatae (Singer, 1986; Bon, 1997, 1998). Also Ferrari (2006) follows these ideas - his I. taxocystis is the same taxon as presented here (I. favrei).

From our molecular data we confirm that also I. favrei has an inter-continental distribution range and seems to be rather homogenous in the molecular data (Fig. 1). In Europe it has a broad geographic distribution but is likely restricted mainly to the alpine zone and especially to the lower alpine zone, associated with Betula nana, various Salix shrubs, $S$. herbacea and S. reticulata on moist places as close to small brooks and in snow bed areas. The three sequences from Alaska, downloaded from Genbank, are isolated from soil and from ECM of Picea mariana, and suggest that it also occurs in North America with a northern distribution in the taiga and boreal forest ecosystems.

In the molecular data, I. rivularis shows a much larger sequence variation than I. favrei. The herein recognized I. rivularis clade receives a week bootstrap support and eight of the sequences form a sub-clade with $84 \%$ support value (Fig. 1). The collections within the sub-clade are mainly collected in boreal to subalpine regions, likely associated with Betula pendula Roth., B. pubescens or B. nana. One of the specimens originates from Estonia and was collected in moist mixed forest. The residual specimens originate from northern boreal forests to the alpine zone, in association with $B$. pubescens, $B$. nana, various Salix shrubs and $S$. herbacea in moist habitats. The species seems to have a northern distribution within Europe, with the most southern confirmed specimens from Estonia. Sequence data of one specimen collected in Canada (Quebec) was included and confirms the species also from North America. With the data at hand the genetic differences cannot be correlated with differences in ecology, geographic distribution or morphology. So, we choose to recognize the major clade despite the low support value.

Inocybe arctica is here described and represents the recovered clade within the complex without a name. Our specimens originate from Svalbard and Fennoscandia, mainly from the arctic and higher alpine zones. On Svalbard it is one of the most common Inocybe species found in mats of Dryas octopetala and with Salix polaris. Specimens from the higher alpine zone in Fennoscandia are also found with $D$. octopetala and S. polaris but also with $S$. reticulata and $S$. herbacea. In comparison to I. rivularis and I. favrei, seems to have preferences for more rich and calcareous soils. Inocybe arctica seems to occur in higher alpine regions in Northern Fennoscandia than I. favrei. Inocybe favrei is not confirmed from Svalbard and 
I. arctica has not yet been confirmed from North America.

\section{Disclosure}

The authors declare no conflict of interest.

\section{Acknowledgments}

Curators of herbaria G, LIP, AH, O are gratefully acknowledged for arranging loans, and Pierre-Arthur Moreau, Gro Gulden, Fernando Esteve-Raventós and Fermin Pancorbo for sharing interesting collections and photos, Seppo Huhtinen and reviewers for valuable comments on the ms. Financial support was received from The Swedish Taxonomy Initiative, ArtDatabanken SLU Uppsala, Anna och Gunnar Vidfelts Fond, Stiftelsen Wilhelm och Martina Lundgrens Vetenskapsfond, and the FinBOL-project funded by the Finnish Cultural Foundation and Kone Foundation.

\section{References}

Alpago Novello, A. (2002). Una specie boreale recentemente descritta: Inocybe rivularis. Bollettino del Gruppo Micologico G. Bresadola, 45, 25-29.

Ariyawansa, H. A., Hawksworth, D. L., Hyde, K. D., Jones, E. B. G. Maharachchikumbura, D. S. M., Manamgoda, D. S., et al. (2014). Epitypification and neotypification: Guidlines with appropriate and inappropriate examples. Fungal Diversity, 69, 57-91. https://doi.org/10.1007/s13225-014-0315-4.

Bon, M. (1985). Quelques nouveaux taxons de la flore mycologique alpine. Bulletin Trimestriel Fédération Mycologique Dauphiné-savoie, 25, 23-30.

Bon, M. (1997). Clé monographique des Inocybes alpins. Bulletin Trimestriel Fédération Mycologique Dauphiné-savoie, 144, 71-109.

Bon, M. (1998). Clé monographique du genre Inocybe (Fr.) Fr. (3ème partie). Documents Mycologiques, 28, 1-45.

Bonsdorff, T. von, Kytövuori, I., Vauras, J., Huhtinen, S., Halme, P., Rämä, T., et al. (2014). Sienet ja metsien luontoarvot. Norrlinia, 27, 1-272.

Cailleux, A. (1981). Notice sur le code des couleurs des sols. Paris: Boubée.

Clark, K., Karsch-Mizrachi, Lipman, D. J., Ostell, J., \& Sayers, E. (2016). Genbank. Nucleic Acids Research, 44. https://doi.org/10.1093/nar/gkv1276. Database issue: D67-D72.

Cripps, C., Larsson, E., \& Horak, E. (2010). Subgenus Mallocybe (Inocybe) in the Rocky Mountain alpine zone with molecular reference to European arctic-alpine material. North American Fungi, 5, 97-126. https://doi.org/10.2509/ naf2010.005.0057.

Drummond, A. J., Suchard, M. A., Xie, D., \& Rambaut, A. (2012). Bayesian phylogenetics with BEAUti and the BEAST 1.7. Molecular Biology and Evolution, 29, 1969-1973. https://doi.org/10.1093/molbev/mss075.

Esteve-Raventós, F., Moreno, G., Alvarado, P., \& Olariaga, I. (2016). Unraveling the Inocybe praetervisa group through type studies and its data: Inocybe praetervisoides sp. nov. From the mediterranean region. Mycologia, 108,123-134. https:// doi.org/10.3852/15-053.

Esteve-Raventós, F., Moreno, G., Bizio, E., \& Alvarado, P. (2015). Inocybe flavobrunnescens, a new species in section Marginatae. Mycological Progress, 14(14). https://doi.org/10.107/s11557-015-1036-0.

Favre, J. (1955). Les champignons supérieurs de la zone alpine du Parc National Suisse. Ergebnisse der Wissenschaftlichen Untersuchungen des Schweizerischen National Parks, 5, 1-212.

Ferrari, E. (2006). Inocybe alpine e subalpine. Fungi Non Delineati, 34-36, 1-457.

Gardes, M., \& Bruns, T. D. (1993). ITS primers with enhanced specificity for basidiomycetes -application to the identification of mycorrhizas and rusts. Molecular Ecology, 2, 113-118. https://doi.org/10.1111/j.1365-294X.1993.tb00005.x.
Hopple, J. S., Jr., \& Vilgalys, R. (1999). Phylogenetic relationships in the mushroom genus Coprinus and dark spored allies based on sequence data from the nuclear gene coding for the large ribosomal subunit RNA: Divergent domains, outgroups, and monophyly. Molecular Phylogeny and Evolution, 13, 1-19. https:// doi.org/10.1006/mpev.1999.0634.

Horak, E. (1987). Asterosporina in the alpine zone of the Swiss National Park (SNP) and adjacent regions. Arctic and Alpine Mycology, 2, 205-235.

Jacobsson, S., \& Larsson, E. (2012). Inocybe (Fr.) Fr. In H. Knudsen, \& J. Vesterholt (Eds.), Funga Nordica (Agaricoid, boletoid, clavarioid, cyphelloid and gastroid genera) (pp. 981-1021). Copenhagen: Nordsvamp.

Jacobsson, S., \& Vauras, J. (1989). [1990]. Inocybe rivularis, a new boreal agaric. Windahlia, 18, 15-24.

Katoh, K., \& Standley, D. M. (2013). MAFFT multiple sequence alignment software version 7: Improvements in performance and usability. Molecular Biology and Evolution, 30, 772-780. https://doi.org/10.1093/molbev/mst010.

Kobayashi, T. (1995). A new species from Tokyo, I. fastuosa spec. nov. Mycologia Helvetica, 7, 7-13.

Kokkonen, K., \& Vauras, J. (2012). Eleven new boreal species of Inocybe with nodulose spores. Mycological Progress, 11, 299-341. https://doi.org/10.1007/s11557011-0783-9.

Kõljalg, U., Nilsson, R. H., Abarenkov, K., Tedersoo, L., Taylor, A. F. S., Bahram, M., et al. (2013). Towards a unified paradigm for sequence-based identification of fungi. Molecular Ecology, 22, 5271-5277. https://doi.org/10.1111/mec.12481.

Kühner, R. (1933). Notes sur le genre Inocybe. 1) Les Inocybes goniosporés (Fin). Bulletin trimestriel de la Société mycologique de France, 49, 81-121.

Larsson, A. (2014). AliView: a fast and lightweight alignment viewer and editor for large data sets. Bioinformatics, 22, 3276-3278. https://doi.org/10.1093/bioinformatics/btu531.

Larsson, E., \& Jacobsson, S. (2004). The controversy over Hygrophorus cossus settled using ITS sequence data from 200-year-old type material. Mycological Research, 108, 781-786. https://doi.org/10.1017/S0953756204000310.

Larsson, E., Vauras, J., \& Cripps, C. L. (2014). Inocybe leiocephala, a species with an intercontinental distribution range - disentangling the I. leiocephala - subbrunnea - catalaunica morphological species complex. Karstenia, 54, 15-39.

Nylander, J. A. A. (2004). MrModeltest v2. - program distributed by the author. Uppsala: Evolutionary Biology Centre, Uppsala University.

Ronquist, F., \& Heulsenbeck, J. P. (2012). MrBayes 3.2, efficient Bayesian phylogenetic inference and model choice across a large model space. Systematic Biology, 61, 539-542. https://doi.org/10.1093/sysbio/sys029.

Ryberg, M., Larsson, E., \& Jacobsson, S. (2010). An evolutionary perspective on morphology and ecological characters in the mushroom family Inocybaceae (Agaricomycotina, Fungi). Molecular Phylogenetics and Evolution, 55, 431-442. https://doi.org/10.1016/j.ympev.2010.02.011.

Schoch, C. L., Seifert, K. A., Huhndorf, S., Robert, V., Spouge, J. L., Levesque, C. A., et al., Fungal Barcoding Consortium. (2012). Nuclear ribosomal internal transcribed spacer (ITS) region as universal DNA barcode marker for Fungi. Proceedings of the National Academy of Science of the United States of America, 109, 6241-6246. https://doi.org/10.1073/pnas.1117018109.

Senn-Irlet, B. (1992). Botanischer Reichtum am Weg von Davos über die Bergüner Furgga zum Albula. Sommerexkursion 1991 in Anklang an die erste Exkursion der Schweizerischen Botanischen Gesellschraft: 6. Macromyzeten (Basidiomycota, Agaricales, Aphyllophorales). Botanica Helvetica, 102, 49-59.

Singer, R. (1986). The Agaricales in modern taxonomy (4th ed.). Koenigstein: Koeltz Scientific Books.

Swofford, D. L. (2003). PAUP*. Phylogenetic analysis using parsimony (* and other methods). Version 4. Sunderland, MA: Sinauer Associates.

Vauras, J., \& Kokkonen, K. (2009). Finnish records on the genus Inocybe. The new species Inocybe saliceticola. Karstenia, 48, 57-67.

Vauras, J., \& Larsson, E. (2015). [2016]. Inocybe caprimulgi and I. lacunarum, two new nodulose-spored species from Fennoscandia. Karstenia, 55, 1-18.

White, T. J., Bruns, T., Lee, L., \& Taylor, J. W. (1990). Amplification and direct sequencing of fungal ribosomal RNA genes for phylogenetics. In M. A. Innis, D. H. Gelfand, J. J. Sininski, \& T. J. White (Eds.), PCR protocols: A guide to methods and applications (pp. 315-322). San Diego: Academic Press. 